\title{
Chromatographic Comparison of Self-Immobilized and Radiation-Immobilized Poly(methyloctylsiloxane) Stationary Phases on Various Silicas
}

\author{
Tania A. Anazawa, Kenneth E. Collins and Isabel Cristina S. F. Jardim*,\# \\ Instituto de Química, Universidade Estadual de Campinas, CP 6154, 13084-971 Campinas - SP, Brazil
}

\begin{abstract}
Dois tipos de fase estacionária, auto-imobilizada e imobilizada por radiação, foram preparadas com poli(metiloctilsiloxano) sobre oito suportes de sílica com tamanho e forma de partículas, e tamanho de poros diferentes. As colunas recheadas com as fases estacionárias preparadas através dos dois procedimentos de imobilização apresentaram eficiências, resoluções e fatores de separação similares, mas as colunas recheadas com a fase estacionária auto-imobilizada tiveram percentagens de carga menores e, portanto, fatores de retenção menores. Os resultados evidenciam diferenças estruturais entre as fases.
\end{abstract}

Self-immobilized and radiation-immobilized stationary phases were prepared with poly(methyloctylsiloxane) on eight silica supports having different particle sizes, particle shapes and pore sizes. Columns prepared by the two immobilization procedures had similar efficiencies, resolutions and separation factors but columns with self-immobilized stationary phases had lower percent loadings and, thus, lower retention factors. Results show structural differences between the phases.

Keywords: silica, radiation immobilization, stationary phase, poly(metyloctylsiloxane)

\section{Introduction}

Silica-based reversed-phase high-performance liquid chromatography (RP-HPLC) has become the method of choice for most liquid chromatographic separations. Much of this popularity can be attributed to the silica itself because of the wide variety of available pore diameters, the uniformity of the pores, the high specific surface areas, the high mechanical strength and chemical reactivity for easy functionalization by reactions with the surface silanol groups. ${ }^{1,2}$ This reactivity, although the key to the success of silica supports, is also a source of its limitations. Silanol groups that are not removed or covered lead to irreversible adsorption of basic solutes and strong peak asymmetry. ${ }^{3}$

Organic polymers have been sorbed onto, or produced on, the surfaces of HPLC silica to obtain more complete coverage, hence more efficient shielding of residual silanol groups. ${ }^{4}$ The LabCrom group (UNICAMP) has been developing such stationary phases by coating poly(methyloctylsiloxane) (PMOS) onto chromatographic silica particles, ${ }^{5-7}$ then immobilizing these phase by $\gamma$ irradiation $^{8-11}$ and by self-immobilization at ambiente temperature. ${ }^{12}$

* e-mail: icsfj@iqm.unicamp.br

\# This papaer is dedicated to professors Kenneth and Carol Collins
In the present work we directly compare the physical and chromatographic properties of PMOS phases that have been immobilized by $\gamma$-irradiation or by selfimmobilization upon the surfaces of various HPLC-silica supports.

\section{Experimental}

\section{Reagents and materials}

Analytical-reagent grade or HPLC-grade solvents were obtained from Merck (Rio de Janeiro, RJ, Brazil) (methanol, dichloromethane, carbon tetrachloride, acetone, benzonitrile, benzene, toluene and naphthalene) and not further purified. Water was distilled and then purified through a Milli-Q system from Millipore.

Poly(methyloctylsiloxane) (PMOS) polymer (average molar mass of 6200 , viscosity $600-1000 \mathrm{cSt}, 25^{\circ} \mathrm{C}$ ) was obtained from Hüls America (Pescataway, NJ, USA).

The silicas tested as chromatographic supports were Davisil, $10 \mu \mathrm{m}$, irregular (Alltech Associates, USA), Sigma, $10 \mu \mathrm{m}$, irregular (Sigma, USA), Lichrosorb Si-100, $10 \mu \mathrm{m}$, irregular and Lichrosorb Si-60, 10, 7 and $5 \mu \mathrm{m}$, irregular (Merck, Germany) and Spherisorb, 8 and $5 \mu \mathrm{m}$, spherical (Phase Separations, UK). 
Preparation of stationary phase and immobilization by gamma irradiation

A known quantity of silica (dried at $150{ }^{\circ} \mathrm{C}$ for $24 \mathrm{~h}$ ) was added to a solution of PMOS in dichloromethane to prepare a PMOS-loaded material, $\mathrm{SiO}_{2}(\mathrm{PMOS})$, having an initial loading of $40 \%$ or $50 \%$ PMOS. This mixture was slowly agitated at room temperature for three hours and then the solvent was allowed to evaporate, without stirring, at room temperature in the fume hood.

Samples of $5.0 \mathrm{~g}$ of prepared stationary phase were sealed in glass ampoules under air. The sealed samples were irradiated to 80 or $120 \mathrm{kGy}$ (irregular silicas) ${ }^{8}$ or 20 kGy (spherical silicas) of absorbed dose, using an industrial Cobalt-60 source (IBRAS-CBO, Campinas, SP, Brazil).

\section{Physical and chemical characterization}

The elemental analyses of the immobilized stationary phases were obtained with a Model CHN-2400 PerkinElmer analyzer.

Specific surface areas of the various packings were determined by the conventional BET method ${ }^{13}$ using a Model 2300 Micromeritics Flow Sorb II instrument.

Infrared spectroscopy was done with a Perkin-Elmer Model 1600 FT-IR spectrophotometer and thermogravimetric analysis with a TA Instruments 2050 TGA.

Solvent extractions were done with a series of three independent extractions (with methanol, benzene and dichloromethane) of six hours each, on each sample, in a Soxhlet extractor using a modification of the method of Sanchez et al.. ${ }^{14}$ After each extraction the solvent was evaporated from the sample and the remaining mass was determined before initiating the next extraction.

\section{Column packing}

Columns (125 mm x $3.4 \mathrm{~mm}$ i.d.) were made locally from type 316 stainless tubing whose inner surface was highly polished in our laboratory. ${ }^{15}$ The columns were slurry packed using $10 \%$ (irregular) or 20\% (spherical) slurries (m/ v) of the stationary phase in carbon tetrachloride. A packing pressure of $38 \mathrm{MPa}$ (Haskel Packing Pump) was used, with methanol as propulsion solvent. Columns were conditioned for four hours with mobile phase (methanol:water, 70:30, v/ v) at $0.2 \mathrm{~mL} \mathrm{~min}^{-1}$ prior to testing.

\section{Chromatographic evaluation}

Chromatographic evaluations were performed with a modular HPLC instrument, equipped with a Waters Model 510 pump, SSI Model 3XL pneumatic injector with a $10 \mu \mathrm{L}$ loop, a Waters Model 481 spectrophotometric detector (14 $\mu \mathrm{L}$ cell volume) and a Waters Model 740 integrator.

All measurements were carried out at ambient temperature using methanol-water mobile phase at a flowrate of $0.2 \mathrm{~mL} \mathrm{~min}^{-1}$, near the optimal flow-rate as determined by a van Deemter plot. The column dead time, $\mathrm{t}_{\mathrm{M}}$, was determined using methanol as an unretained compound.

Two test mixtures were used in this study: (I) acetone, benzonitrile, benzene, toluene and naphthalene and (II) aniline, $o-, m-, p$-toluidine, and $N, N$-dimethylaniline. In mixture I, a mobile phase of $\mathrm{MeOH}: \mathrm{H}_{2} \mathrm{O} 70: 30(\mathrm{v} / \mathrm{v})$ was used while for mixture II, the mobile phase was $\mathrm{MeOH}: \mathrm{H}_{2} \mathrm{O}$ $55: 45(\mathrm{v} / \mathrm{v})$. Injections were of $10 \mu \mathrm{L}$ with $\mathrm{UV}$ detection at $254 \mathrm{~nm}$.

Chromatographic performance was evaluated by means of the efficiency (plates $/ \mathrm{m}, \mathrm{N} / \mathrm{L}$ ), retention factor $(\mathrm{k})$, resolution $\left(\mathrm{R}_{\mathrm{s}}\right)$, separation factor $(\alpha)$ and asymmetry factor (As), manually determined from the chromatograms. The asymmetry factor was calculated at $10 \%$ of the peak height. ${ }^{16}$

\section{Results and Discussion}

The infrared spectra of some self-immobilized and $\gamma$ immobilized stationary phases (Figure 1) show that the intensity of the signals characteristic of PMOS (2900, 1466 and $1258 \mathrm{~cm}^{-1}$ ) present a slight increase in intensity in the immobilized stationary phases due to the larger amount of PMOS in the silicas, as a result of cross-linking of the PMOS - as is also indicated by the results of solvent extraction and \% carbon.

Table 1 lists physical data (particle shape, particle size, pore size, specific volume and specific surface area) of each of the silicas prior to PMOS loading, the \% of PMOS contained in test-column after packings (vertical columns 7 and 8), the \% PMOS contained in samples of PMOS loaded silicas following exhaustive extraction by methanol, benzene and dichloromethane (columns 9 and 10). The data for columns 7 to 10 indicate the quantities of immobilized PMOS present in samples from which nonimmobilized PMOS has been extracted - either by the packing and testing procedure (columns 7 and 8 ) or by the 3 -solvent extraction procedure (columns 9 and 10). From these data we see the similarities in amounts of immobilized PMOS in the various irregular silicas. As expected, we also see larger amounts of PMOS are immobilized by $\gamma$-irradiation ${ }^{8}$ than by self-immobilization. ${ }^{7}$ Columns 11 and 

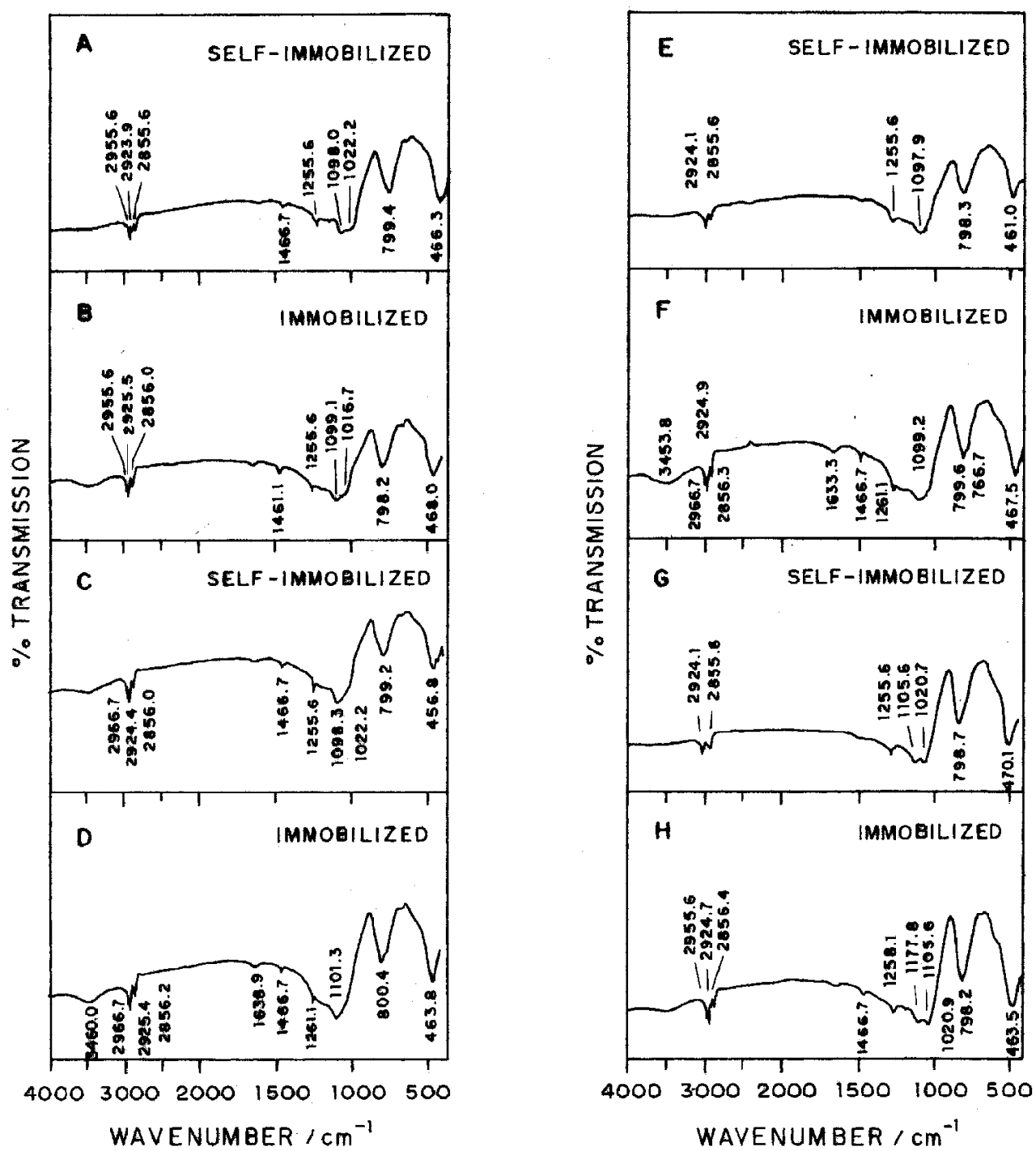

Figure 1. Infrared spectra of self-immobilized and $\gamma$-immobilized stationary phases for (A and B) 50\% PMOS-Sigma, (C and D) 50\% PMOSLichrosorb Si-100, ( E and F) 50\% PMOS-Lichrosorb Si-60, $7 \mu \mathrm{m}$, (G and H) 40\% PMOS-Spherisorb, $8 \mu \mathrm{m}$, respectively.

Table 1. Physical and chemical characteristics of self-immobilized and $\gamma$-immobilized stationary phases

\begin{tabular}{|c|c|c|c|c|c|c|c|c|c|c|c|}
\hline \multirow{2}{*}{$\begin{array}{c}1 \\
\text { Stationary phases } \\
\text { (\% PMOS in initial } \\
\text { loading) }\end{array}$} & \multirow{2}{*}{$\begin{array}{c}2 \\
\text { Particle } \\
\text { shape }\end{array}$} & \multirow{2}{*}{$\begin{array}{c}3 \\
\text { Silica } \\
\text { particle } \\
\text { size } \\
(\mu \mathrm{m})\end{array}$} & \multirow{2}{*}{$\begin{array}{c}4 \\
\text { Silica } \\
\text { pore } \\
\text { size } \\
(\mathrm{nm})\end{array}$} & \multirow{2}{*}{$\begin{array}{c}5 \\
\text { Silica } \\
\text { specific } \\
\text { volume } \\
\left(\mathrm{mL} \mathrm{g}^{-1}\right)\end{array}$} & \multirow{2}{*}{$\begin{array}{c}6 \\
\text { Silica } \\
\text { specific } \\
\text { surface } \\
\text { area } \\
\left(\mathrm{m}^{2} \mathrm{~g}^{-1}\right)\end{array}$} & \multicolumn{2}{|c|}{$\begin{array}{c}\% \text { PMOS } \\
\text { after packing }\end{array}$} & \multicolumn{2}{|c|}{$\begin{array}{c}\% \text { PMOS } \\
\text { after extractions }\end{array}$} & \multicolumn{2}{|c|}{$\begin{array}{c}\% \text { PMOS ratio } \\
\text { (self-immob./g-immob.) }\end{array}$} \\
\hline & & & & & & $\begin{array}{c}7 \\
\text { self-immob. }\end{array}$ & $\begin{array}{c}8 \\
\gamma \text {-immob. }\end{array}$ & $\begin{array}{c}9 \\
\text { self-immob. }\end{array}$ & $\begin{array}{c}10 \\
\gamma \text {-immob. }\end{array}$ & $\begin{array}{c}11 \\
\text { after } \mathrm{P}^{\mathrm{c}}\end{array}$ & $\begin{array}{c}12 \\
\text { after } X^{d}\end{array}$ \\
\hline 40\% PMOS-Davisil & irregular & 10 & 15 & 1.6 & 237 & 18.6 & 26.3 & 18.5 & 25.1 & 0.71 & 0.74 \\
\hline 50\% PMOS-Sigma & irregular & 10 & 6 & 1.1 & 393 & 28.5 & 35.0 & 24.4 & 29.2 & 0.81 & 0.83 \\
\hline $50 \%$ PMOS-Si-100 & irregular & 10 & 10 & 1.25 & 290 & 27.3 & 39.5 & 26.9 & 34.1 & 0.69 & 0.79 \\
\hline $50 \%$ PMOS-Si-60 & irregular & 10 & 6 & 0.9 & 267 & - & 35.5 & 19.9 & 28.5 & - & 0.70 \\
\hline $50 \%$ PMOS-Si-60 & irregular & 7 & 6 & 0.9 & 305 & 29.0 & 34.8 & 20.2 & 29.4 & 0.83 & 0.69 \\
\hline $50 \%$ PMOS-Si-60 & irregular & 5 & 6 & 0.9 & 402 & 30.3 & 32.9 & 23.4 & 26.9 & 0.92 & 0.87 \\
\hline 40\% PMOS-Spher. & spherical & 8 & 8 & 0.45 & 149 & 24.0 & 24.3 & 17.0 & 18.0 & 0.99 & 0.94 \\
\hline 40\% PMOS-Spher. & spherical & 5 & 8 & 0.45 & 186 & 21.8 & - & 17.9 & 18.8 & - & 0.95 \\
\hline
\end{tabular}

a $\%$ PMOS obtained from the $\% \mathrm{C}$ of used packing material by dividing the $\% \mathrm{C}$ by the carbon fraction $(0.62)$ of PMOS; ${ }^{\text {b } \% ~ P M O S ~ o b t a i n e d ~ f r o m ~}$ the $\% \mathrm{C}$ of non-used (non-packed) packing material following a series of extractions (methanol, benzene, dichloromethane); ${ }^{\mathrm{c}}$ after $\mathrm{P}=\mathrm{after}$ packing; ${ }^{\mathrm{d}}$ after $\mathrm{X}=$ after extractions. 
12 of Table 1 give estimates of the relative quantities of PMOS immobilized by the two immobilization procedures.

Thermogravimetric analyses (Figure 2) show good thermal stability of self-immobilized and $\gamma$-immobilized stationary phases in the temperature range used for HPLC,
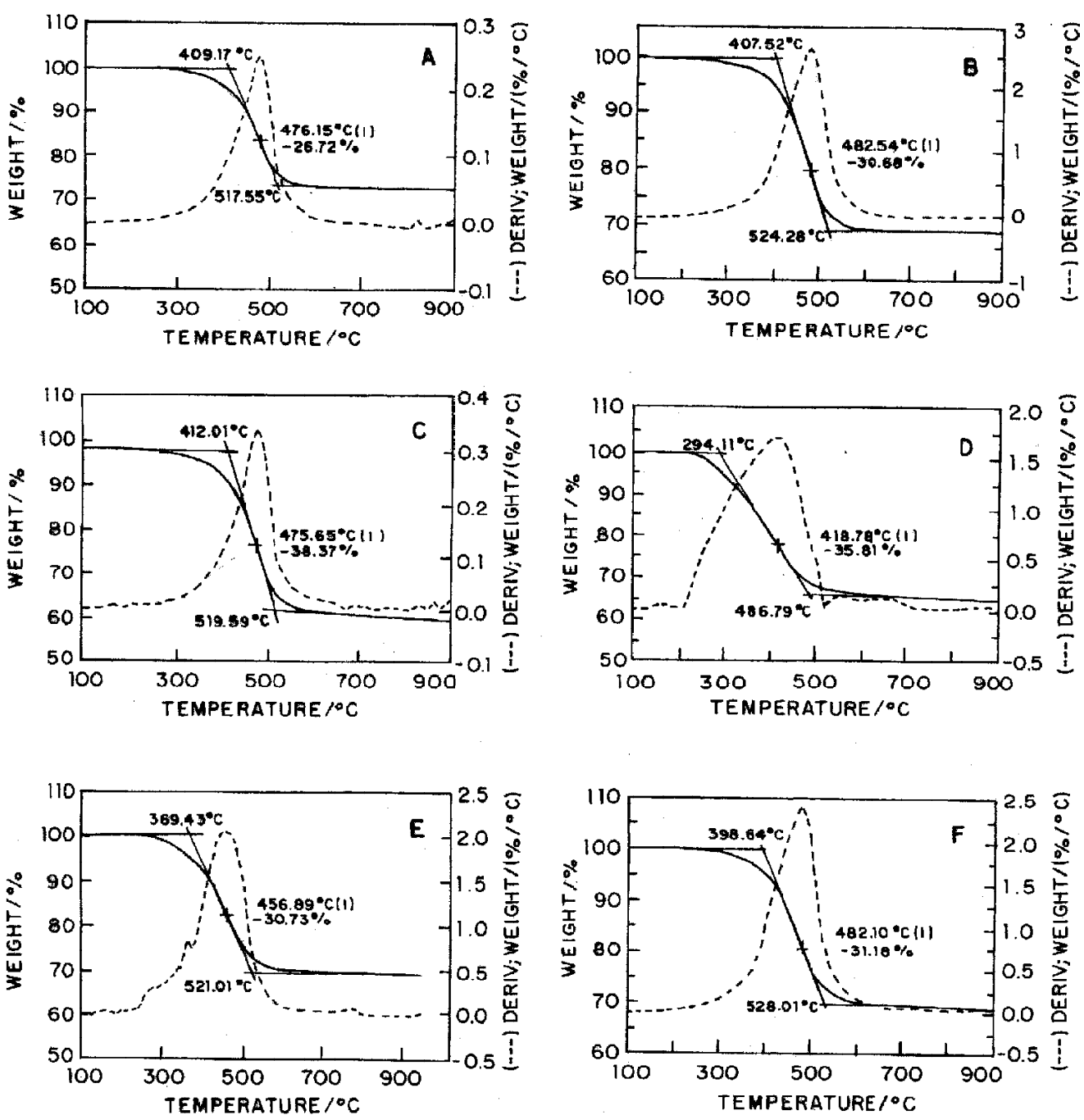

Figure 2. Thermograms of self-immobilized and $\gamma$-immobilized stationary phases for (A and B) $40 \%$ PMOS-Davisil, (C and D) $50 \%$ PMOSLichrosorb Si-60, $10 \mu \mathrm{m}$, (E and F) 40\% PMOS-Spherisorb, $5 \mu \mathrm{m}$, respectively.

Table 2. Comparisons of column efficiencies ${ }^{\mathrm{a}}$

\begin{tabular}{|c|c|c|c|c|c|}
\hline \multirow[t]{2}{*}{ Stationary phase } & \multirow{2}{*}{$\mathrm{d}_{\mathrm{p}}(\mu \mathrm{m})$} & \multicolumn{2}{|c|}{$\mathrm{N} / \mathrm{L}$} & \multicolumn{2}{|c|}{$(\mathrm{N} / \mathrm{L})_{5}{ }^{\mathrm{b}}$} \\
\hline & & Self-immob. & $\gamma$-immob. & Self-immob. & $\gamma$-immob. \\
\hline Davisil & 10 & 24000 & 26400 & 62400 & 68640 \\
\hline Sigma & 10 & 34400 & 36400 & 68800 & 72800 \\
\hline $\mathrm{Si}-100$ & 10 & 33600 & 36400 & 67200 & 72800 \\
\hline Si-60 & 10 & $35 \quad 200$ & 43600 & 70400 & $87 \quad 200$ \\
\hline $\mathrm{Si}-60$ & 7 & 41200 & 37600 & 57700 & 52640 \\
\hline Si-60 & 5 & 50400 & 66400 & 50400 & 66400 \\
\hline Spherisorb & 8 & 58400 & 39600 & 93440 & 63400 \\
\hline \multirow[t]{2}{*}{ Spherisorb } & 5 & 74400 & 70400 & 74400 & 70400 \\
\hline & & & mean & 68090 & 69280 \\
\hline
\end{tabular}

a efficiencies were obtained from the naphthalene peak of test mixture $\mathrm{I}$; ${ }^{\mathrm{b}}(\mathrm{N} / \mathrm{L})_{5}=$ plates per meter normalized to $5 \mu \mathrm{m}$ particle size by the factor $\mathrm{d}_{\mathrm{p}} / 5$. For example: for the case of $10 \mu \mathrm{m}$ particles, $(\mathrm{N} / \mathrm{L})_{5}=(\mathrm{N} / \mathrm{L})_{10} \times 10 / 5$. 
columns packed with the stationary phases. The efficiencies normalized to $5 \mu \mathrm{m}$ particles, $(\mathrm{N} / \mathrm{L})_{5}$, show that column efficiencies are, on the average, no better for $\gamma$-immobilized PMOS phases than for self-immobilized phases. Nevertheless the overall average efficiency of almost 70000 plates per meter compares well with commercial phases.

Table 3 shows that, for the test solutes of mixture I, the As, Rs and $\alpha$ values do not differ greatly between the different silicas or for the two immobilization procedures. The $\mathrm{k}$ values, however, show consistent differences for the two immobilization procedures: the $\gamma$-immobilized stationary phases, with their greater \% PMOS values, have consistently higher $\mathrm{k}$, probably due to the thickness of the PMOS coating, so there is a decrease in the velocity of mass transfer and, consequently, an increase in the retention factor (Figure 3). This seems to imply that the selfimmobilized stationary phases, with separation efficiencies similar to those of the $\gamma$-immobilized phases, can perform separations faster, which could be a decided advantage.

Table 4 shows the results obtained using test mixture II, part of the mixture proposed by Engelhardt and coworkers ${ }^{17,18}$ as basic probes, with aniline as a weak base, $\mathrm{N}, \mathrm{N}$-dimethylaniline (N,N-DMA) as a strong base, and the isomeric $o-, m$ - and $p$-toluidines as probes for silanophilic interactions. Methanol:water (55:45, v/v), without addition of buffer or salt solution, was used as the mobile phase. A column can be considered "good" for the analysis of basic compounds, according to the Engelhardt criteria ${ }^{17,18}$ if the isomeric toluidines coelute or have value below 1.3. The findings obtained from self-immobilized stationary phases were discussed in previous work. ${ }^{7}$

Table 4 reveals that, although the separation factors $(\alpha)$ for the toluidines may be quite similar for both the selfimmobilized and $\gamma$-immobilized phases, the asymmetry factors for N,N-DMA tend to be consistently different, thus pointing again to the possibility that the actual interaction surfaces of the stationary phases which are immobilized in different ways have fundamentally different structures, as
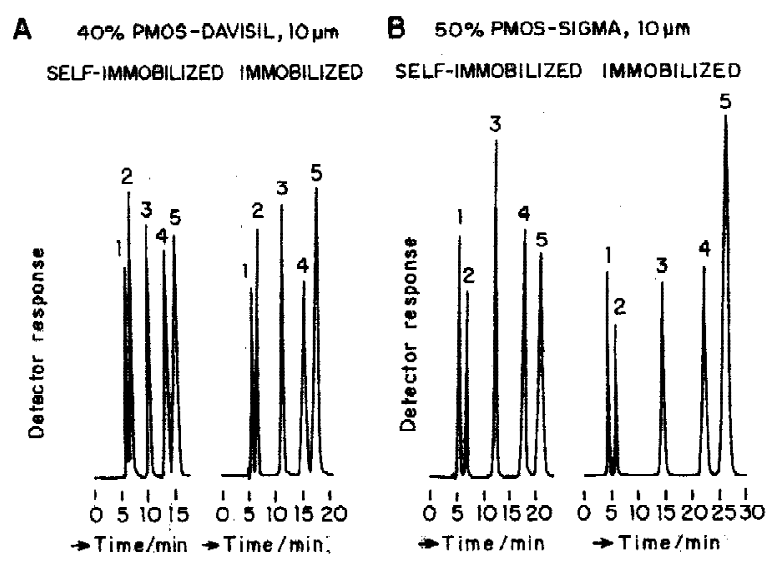

C
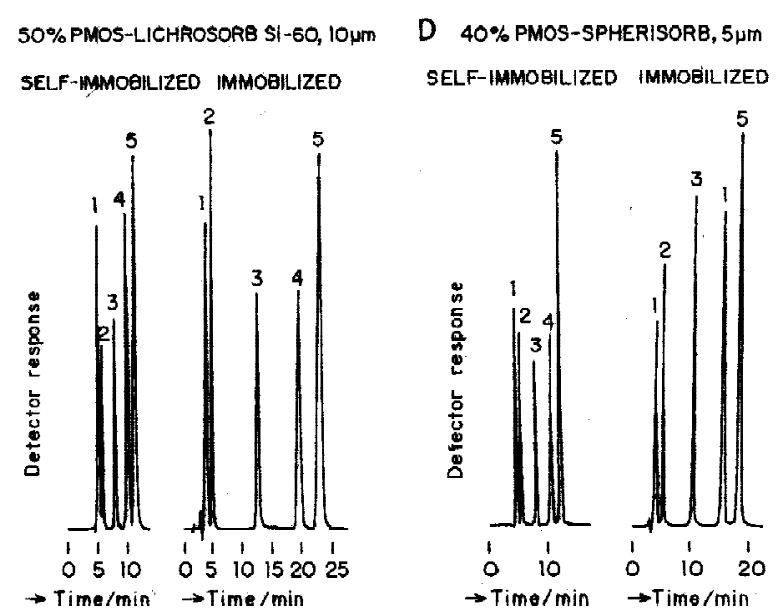

Figure 3. Chromatograms of test mixture I: $1=$ acetone, $2=$ benzonitrile, 3 = benzene, $4=$ toluene and $5=$ naphthalene, obtained with columns packed with: (A) 40\% PMOS-Davisil self-immobilized and $\gamma$-immobilized, (B) 50\% PMOS-Sigma self-immobilized and $\gamma$ immobilized, (C) 50\% PMOS- Lichrosorb Si-60, $10 \mu \mathrm{m}$, self-immobilized and $\gamma$-immobilized, (D) $40 \%$ PMOS-Spherisorb, $5 \mu \mathrm{m}$, selfimmobilized and $\gamma$-immobilized. Chromatographic conditions: mobile phase: methanol:water $(70: 30, \mathrm{v} / \mathrm{v})$, flow-rate: $0.2 \mathrm{~mL} \mathrm{~min}{ }^{-1}$, volume of injected sample: $10 \mu \mathrm{L}$, detection: UV, $254 \mathrm{~nm}$.

opposed to, for example, simply having somewhat more complete coverage or a thicker layer of PMOS having the same surface structure.

Table 3. Chromatographic parameters obtained using test mixture I

\begin{tabular}{|c|c|c|c|c|c|c|c|c|c|}
\hline \multirow{2}{*}{$\begin{array}{l}\text { Stationary Phase } \\
\text { (\% Initial Loading) }\end{array}$} & \multirow{2}{*}{$\begin{array}{l}\mathrm{d}_{\mathrm{p}} \\
(\mu \mathrm{m})\end{array}$} & \multicolumn{2}{|c|}{$A s^{a}$} & \multicolumn{2}{|c|}{$\mathrm{k}^{\mathrm{a}}$} & \multicolumn{2}{|c|}{$\mathrm{R}_{\mathrm{s}}{ }^{\mathrm{b}}$} & \multicolumn{2}{|c|}{$\alpha^{\mathrm{b}}$} \\
\hline & & Self-immob. & $\gamma$-immob. & Self-immob. & $\gamma$-immob. & Self-immob. & $\gamma$-immob. & Self-immob. & $\gamma$-immob. \\
\hline 40\% PMOS-Davisil & 10 & 1.4 & 1.3 & 1.8 & 2.5 & 1.8 & 1.9 & 1.2 & 1.2 \\
\hline 50\% PMOS-Sigma & 10 & 1.1 & 1.2 & 3.6 & 6.6 & 2.7 & 2.7 & 1.2 & 1.2 \\
\hline $50 \%$ PMOS-Si-100 & 10 & 1.0 & 1.1 & 3.2 & 6.3 & 2.4 & 2.6 & 1.2 & 1.2 \\
\hline $50 \%$ PMOS-Si-60 & 10 & 1.2 & 1.2 & 1.5 & 6.2 & 2.0 & 3.0 & 1.2 & 1.2 \\
\hline $50 \%$ PMOS-Si-60 & 7 & 1.3 & 0.9 & 3.1 & 6.4 & 2.7 & 2.7 & 1.2 & 1.2 \\
\hline $50 \%$ PMOS-Si-60 & 5 & 1.2 & 0.9 & 4.8 & 6.4 & 3.2 & 3.6 & 1.2 & 1.2 \\
\hline 40\% PMOS-Spher. & 8 & 1.0 & 0.7 & 4.1 & 6.5 & 3.4 & 3.0 & 1.2 & 1.2 \\
\hline $40 \%$ PMOS-Spher. & 5 & 1.3 & 0.9 & 2.1 & 4.7 & 3.3 & 4.0 & 1.2 & 1.2 \\
\hline
\end{tabular}

a calculated for the naphthalene peak; ${ }^{\mathrm{b}}$ calculated for the toluene-naphthalene pair. 
Table 4. Chromatographic parameters obtained using test mixture II

\begin{tabular}{|c|c|c|c|c|c|c|c|c|c|c|}
\hline \multirow{3}{*}{$\begin{array}{l}\text { Stationary Phase } \\
\text { (\% Initial Loading) }\end{array}$} & \multirow{3}{*}{$\begin{array}{l}\mathrm{dp} \\
(\mu \mathrm{m})\end{array}$} & \multirow{3}{*}{$\begin{array}{c}\text { Chromatogr. } \\
\text { parameter }\end{array}$} & \multicolumn{8}{|c|}{ Test solute } \\
\hline & & & \multicolumn{2}{|c|}{ Aniline } & \multicolumn{2}{|c|}{ N,N-DMA } & \multicolumn{2}{|c|}{$\mathrm{p}-/ \mathrm{m}-\mathrm{t}$} & \multicolumn{2}{|c|}{$\mathrm{m}-/ \mathrm{o}-\mathrm{t}$} \\
\hline & & & S-I & $\gamma-\mathrm{I}$ & S-I & $\gamma-\mathrm{I}$ & S-I & $\gamma-\mathrm{I}$ & S-I & $\gamma-\mathrm{I}$ \\
\hline \multirow[t]{2}{*}{ 40\% PMOS-Davisil } & 10 & As & 2.5 & 2.2 & 3.3 & 1.9 & & & & \\
\hline & & $\alpha$ & & & & & 1.3 & 1.4 & 1.0 & 1.0 \\
\hline \multirow[t]{2}{*}{$50 \%$ PMOS-Sigma } & 10 & As & 1.3 & $\mathrm{a}$ & 1.2 & $\mathrm{a}$ & & & & \\
\hline & & $\alpha$ & & & & & 1.2 & $\mathrm{a}$ & 1.0 & a \\
\hline \multirow[t]{2}{*}{ 50\%PMOS-Lich.Si-100 } & 10 & As & 1.8 & & 1.9 & 1.1 & & & & \\
\hline & & $\alpha$ & & & & & 1.2 & 1.1 & 1.0 & 2.1 \\
\hline \multirow[t]{2}{*}{ 50\%PMOS-Lich.Si-60 } & 10 & As & 1.5 & $\mathrm{~b}$ & 1.3 & $\mathrm{~b}$ & & & & \\
\hline & & $\alpha$ & & & & & 1.0 & $\mathrm{~b}$ & 1.0 & $\mathrm{~b}$ \\
\hline \multirow[t]{2}{*}{ 50\%PMOS-Lich.Si-60 } & 7 & As & 1.6 & & 1.4 & 3.6 & & & & \\
\hline & & $\alpha$ & & & & & 1.2 & 1.1 & 1.5 & 1.4 \\
\hline \multirow[t]{2}{*}{$50 \%$ PMOS-Lich.Si-60 } & 5 & As & 2.2 & 2.3 & 2.1 & 1.4 & & & & \\
\hline & & $\alpha$ & & & & & 1.0 & 1.0 & 1.4 & 1.5 \\
\hline
\end{tabular}

$\mathrm{p}-\mathrm{m}-\mathrm{t}=\mathrm{p}$-/m-toluidine pair; $\mathrm{m}$-/o- $\mathrm{t}=\mathrm{m}$-/o-toluidine pair; $\mathrm{a}=$ result not reproducible; $\mathrm{b}=$ problems of absorption of the compounds $; \mathrm{S}-\mathrm{I}=$ selfimmobilized $; \gamma$-I $=\gamma$-immobilized.

\section{Conclusions}

Although self-immobilized and $\gamma$-immobilized PMOS phases have similar chromatographic properties, the $\gamma$-immobilized phases show somewhat higher efficiencies and the self-immobilized phases, having lower carbon contents, can give more rapid separations. Both types of immobilized phase may be used at moderately elevated $\mathrm{pH}$.

\section{Acknowledgements}

The authors acknowledge financial support from FAPESP and CNPq and thank IBRAS-CBO (Campinas, $\mathrm{SP}$, Brazil) for performing the irradiations of the stationary phases and Prof. C. H. Collins for helpful discussions and suggestions.

\section{References}

1. Majors, R.E.; LC-GC 1997, 5, 508.

2. Unger, K.K.; Porous Silica: Its Properties and Use as Support in Column Liquid Chromatography, Elsevier: Amsterdam, 1986.

3. Nawrocki, J.; J. Chromatogr. A 1997, 779, 29.

4. Petro, M.; Berek, D.; Chromatographia 1993, 37, 549.

5. Anazawa, T.A.; Jardim, I.C.S.F.; J. Liq. Chromatogr. 1994, 17, 1265.

6. Anazawa, T.A.; Carraro, F.; Collins, K.E.; Jardim, I.C.S.F.; J. Chromatogr. A 1995, 697, 159.
7. Anazawa, T.A.; Jardim, I.C.S.F; J. Liq. Chromatogr. Relat. Technol. 1998, 21, 645.

8. Jardim, I.C.S.F.; Collins, K.E.; Anazawa, T.A.; J. Chromatogr. A 1999, 849, 299.

9. Melo, L.F.C.; Jardim, I.C.S.F.; J. Chromatogr. A 1999, 845, 423.

10. Silva, R.B.; Collins, C.H.; J. Chromatogr. A 1999, 845, 417.

11. Silva, R. B.; Collins, K.E.; Collins, C.H.; J. Chromatogr. A 2000, 869, 137.

12. Collins, K.E.; Bottoli, C.B.G.; Bachmann, S.; Vigna, C.R.M.; Collins, C. H.; Albert, K.; J. Chromatogr. A 2004, in press.

13. Brunauer, S.; Emmett, P.H.; Teller, E.; J. Am. Chem. Soc. 1938, 60, 309.

14. Sanchez, E. F.; Dominguez, J.A.; Munoz , J.E.; Molera, M.J.; J. Chromatogr. 1984, 299, 151.

15. Collins, K.E.; Franchon, A.C.; Jardim, I.C.S.F.; Radovanovic, E.; Gonçalves, M.C.; LC-GC 2000, 18, 106.

16. Snyder, L.R.; Kirkland, J. J.; Glajch, J.L.; Pratical HPLC Method Development, $2^{\text {nd }}$ ed., Wiley: New York, 1997, ch. 5.

17. Engelhardt, H.; Jungheim, M.; Chromatographia 1990, 29 , 59.

18. Engelhardt, H.; Löw, H.; Götzzinger, W.; J. Chromatogr. 1991, 544,371

Received: September 16, 2002 Published on the web: January 19, 2004

FAPESP helped in meeting the publication costs of this article. 